\title{
KEPEMIMPINAN KETUA KELOMPOK TANI DALAM MENINGKATKAN DINAMIKA KELOMPOK DI KECAMATAN NATAR KABUPATEN LAMPUNG SELATAN
}

\author{
(Leadership of The Farmer Group Chairman on Improving The Group Dynamics \\ In Natar Subdistrict of South Lampung Regency)
}

Fernaldi Shidi Hutomo, Irwan Effendi, Serly Silviyanti

Jurusan Agribisnis, Fakultas Pertanian, Universitas Lampung, Jl. Prof. Dr. Soemantri Brojonegoro No.1

Bandar Lampung 35141, Telp 082186163951,e-mail: aldi_fernaldi@yahoo.com

\begin{abstract}
This study aimed to analyze the leadership level of the farmer group chairman, the dynamism level of the farmer group, the relation between farmer grup chairman's leadership and group dynamics, in addition to the relation of group dynamics and rice productivity in Natar Sub-Distict of South Lampung Regency. This study was conducted purposively in Natar Sub-District of South Lampung Regency by survey method, in which respondents consist of 69 farmer groups. The data was collected in September - December 2016. The data was analyzed descriptively and statistically, in which the relation between variables of this study were tested by Rank-Sperman Correlation Test. The results showed that: the leadership level of the farmer group chairman in Natar Sub-District of South Lampung Regency was in good classification, the dynamics level of the group was in quite good classification. The leadership of the farmer group's chairman in Natar Sub-District was significantly related to the group dynamics, whereas group dynamics was not correlated significantly to productivity of rice in Natar Sub-Distric of South Lampung Regency.
\end{abstract}

Key words : group dynamics, leadership, productivity of rice

\section{PENDAHULUAN}

Upaya pembangunan pertanian erat kaitanya dengan upaya pengembangan sumberdaya manusia khususnya para petani (Arifin 2013). Petani adalah komponen yang memainkan peranan inti dalam proses pembangunan pertanian, oleh karena itu petani perlu mempelajari dan menerapkan inovasi atau metode-metode yang akan mengarahkan pada kemajuan dalam usahataninya.

Peran penting sektor pertanian dalam pembangunan perekonomian tidak terlepas dari peranan kelompok tani sebagai fasilitator program pemerintah dengan pelaksana kegiatan. Pada hakikatnya, tujuan kelompok mampu mengikat seluruh anggota kelompok untuk menjadi satu kesatuan kelompok yang dinamis, karena semangat anggota tidak selalu berada dalam keaadan statis, akan tetapi selalu berubah-ubah secara terus menerus dalam menjalankan kehidupan berkelompok.

Tujuan dinamika kelompok adalah tercapainya tujuan kelompok dengan adanya tindakan yang dilakukan oleh anggota kelompok (Mardikanto 1993). Adanya dinamika didalam kelompok mampu memberikan peluang kepada setiap anggota kelompok untuk saling berinteraksi, bekerjasama, mengembangkan kemampuan dan ikut berpartisipasi dalam setiap kegiatan kelompok.

Salah satu faktor yang memperlancar kegiatan usahatani yang dilakukan oleh anggota kelompok dalam mengadopsi inovasi di bidang pertanian adalah adanya keterlibatan ketua kelompok sebagai pemimpin. Melalui kepemimpinan ketua kelompok fungsi kelompok yaitu kelas belajar, unit produksi dan wahana kerjasama antara individu-individu dalam kelompok sebagai upaya untuk meningkatkan produktivitas usahatani dapat tercapai. Sehubungan dengan kepemimpinan ketua kelompok tersebut anggota kelompok berintergrasi, bekerjasama dan berusaha untuk menciptakan kelompok tani yang dinamis untuk mencapai tujuan bersama.

Berdasarkan uraian tersebut, maka tujuan dari penelitian ini adalah untuk mengetahui : tingkat kepemimpinan ketua kelompok tani, tingkat kedinamisan kelompok, hubungan kepemipinan ketua kelompok tani dengan dinamika kelompok di Kecamatan Natar Kabupaten Lampung Selatan dan Menganalisis hubungan dinamika kelompok dengan produktivitas padi di Kecamatan Natar Kabupaten Lampung Selatan. 


\section{METODE PENELITIAN}

Metode penelitian yang digunakan adalah metode survei. Penelitian ini dilakukan di Kecamatan Natar, Kabupaten Lampung Selatan. Lokasi penelitian dipilih secara sengaja (purposive) dengan pertimbangan Kecamatan Natar memiliki tingkat produktivitas padi paling tinggi yaitu 5,69 ton/ha dibandingkan dengan kecamatan-kecamatan lainya di Kabupaten Lampung Selatan, sedangkan kecamatan yang memilki produktivitas padi terendah berada di Kecamatan Bakauheni yaitu 4,41 ton/ha. Pengambilan data dilakukan pada bulan Oktober-Desember 2016. Sampel diambil secara Proportional Simple Random Sampling atau penentuan sampel secara proporsi, yakni 69 kelompok tani dengan responden sebanyak 348 anggota kelompok tani di Kecamatan Natar Kabupaten Lampung Selatan.

Data yang digunakan dalam penelitian ini adalah data primer dan data sekunder. Data primer diperoleh secara langsung melalui proses wawancara pada petani padi dengan bantuan daftar kuesioner. Data sekunder diperoleh dari badan dan instansi terkait di daerah penelitian.

Metode analisis data yang digunakan pada penelitian ini adalah deskriptif, sedangkan pengujian hipotesis menggunakan statistik nonparametrik korelasi Rank Spearman (Siegel 1986) dengan menggunakan rumus:

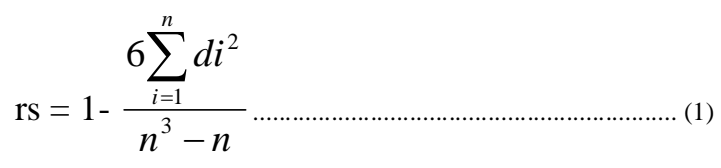

Keterangan:

rs : Koefisien korelasi

di : Perbedaan pasangan setiap peringkat

$\mathrm{n}$ : Jumlah sampel

Karena jumlah sampel yang digunakan adalah lebih besar dari 10 (sepuluh) responden, maka pengujian terhadap Ho dilanjutkan dengan Uji-t dengan rumus:

$\mathrm{t}_{\text {hitung }}=\mathrm{rs} \sqrt{\frac{n-2}{1-r s^{2}}}$

Keterangan:

$\mathrm{t}_{\text {hitung }} \quad$ : Nilai $\mathrm{t}$ yang dihitung

$\mathrm{n} \quad$ : Jumlah sampel penelitian
Kriteria pengambilan keputusan:

1. Jika $t_{\text {hitung }} \leq \mathrm{t}_{\text {tabel }}(\mathrm{n}-2)$ maka tolak H1 pada $\alpha$ 0.05 atau $\alpha 0.01$, artinya tidak ada hubungan nyata pada kedua variabel.

2. Jika $\mathrm{t}_{\text {hitung }}>\mathrm{t}_{\text {tabel }}(\mathrm{n}-2)$, maka terima $\mathrm{H} 1$ pada $\alpha$ 0.05 atau $\alpha 0.01$, artinya terdapat hubungan yang nyata pada kedua variabel.

Variabel pada penelitian ini yaitu kepemimpinan $(\mathrm{X})$, dinamika kelompok (Y) dan Produktivitas padi (Z). kepemimpinan dilihat dari indikator Sifat pemimpin, perilaku pemimpin dan kekuasaan pemimpin (Kartono 2006). Dinamika kelompok dilihat dari indikator tujuan kelompok, struktur kelompok, fungsi tugas, pembinaan dan pemeliharaan kelompok, ke kompakan kelompok, suasana kelompok, tekanan kelompok, keefektifan kelompok dan agenda terselubung

(Mardikanto 1993).

Pengukuran variabel $\mathrm{X}$ (kepemimpinan) dalam penelitian ini menggunakan teknik skor dengan skor 1-3 yang diklasifikasikan ke dalam tiga kategori. Kepemimpinan diukur dengan 3 indikator yaitu, sifat pemimpin, prilaku pemimpin dan kekuasaan pemimpin. Pengukuran variabel $\mathrm{Y}$ (dinamika kelompok) dalam penelitian ini menggunakan teknik skor, dengan skor 1-3 yang diklasifikasikan ke dalam tiga kategori. Dinamika kelompok diukur dengan indikator yaitu tujuan kelompok, struktur kelompok, fungsi tugas, pembinaan dan pemeliharaan kelompok, ke kompakan kelompok, suasana kelompok, tekanan kelompok, keefektifan kelompok dan agenda terselubung.

\section{HASIL DAN PEMBAHASAN}

\section{Kondisi Daerah Penelitian dan Karakteristik Responden}

Kecamatan Natar merupakan salah satu kecamatan di Kabupaten Lampung Selatan yang memiliki luas lahan 25.374 ha dan sebesar 30,68 persen dari total luas lahan merupakan lahan sawah. Mayoritas penduduk di Kecamatan Natar merupakan Suku Jawa. Jumlah penduduk yaitu sebanyak 173.391 jiwa dengan usia berkisar 31-40 tahun. Kelembagaan di Kecamatan Natar terdiri dari 221 kelompok tani, 25 gabungan kelompok tani dan 1 P3A (BP3K Kecamatan Natar 2015).

\section{Kepemimpinan}

Kepemimpinan pada hakikatnya menunjukkan bentuk dan cara pemimpin dalam menggerakkan 
bawahannya melalui proses interaksi untuk saling bekerjasama dalam upaya untuk mencapai tujuan kelompok (Kartono 2006).

Tabel 1 menunjukkan rekapitulasi kepemimpinan ketua kelompok yang diukur dalam tiga indikator yaitu sifat pemimpin, perilaku pemimpin dan kekuasaan pemimpin. Berdasarkan Tabel 1 data rekapitulasi kepemimpinan menjelaskan bahwa sebanyak 50,73 persen atau 35 kelompok berada pada klasfikasi cukup baik. Berdasarkan kondisi dilapangan ketua kelompok tani yang ada di Kecamatan Natar Kabupaten Lampung Selatan bersedia dalam memimpin rapat, memberikan pendampingan dalam usahatani padi seperti penanaman, perawatan, pascapanen, memberikan informasi mengenai hasil keputusan rapat dan usahatani padi serta memberikan kebebasan kepada anggota kelompok dalam berusahatani sesuai dengan kemampuan yang dimiliki oleh setiap anggota kelompok. Uraian mengenai kepemimpinan ketua kelompok dari masingmasing indikator yaitu sifat pemimpin, perilaku pemimpin dan kekuasaan pemimpin dapat dilihat pada Tabel 2. Berikut ini penjelasan dari setiap indikator kepemimpinan ketua kelompok tani dalam meningkatkan dinamika kelompok di Kecamatan Natar Kabupaten Lampung Selatan.

Sifat pemimpin

Berdasarkan hasil penelitian diketahui bahwa sifat pemimpin ketua kelompok tani berada pada klasifikasi cukup baik (42,03\%). Sebagian besar ketua kelompok mempunyai sifat yang cukup baik ,hal ini dibuktikan ketika ketua kelompok memimpin rapat ketua kelompok tani memberikan informasi/ keterampilan kepada anggota dan ketua kelompok tani melakukan pendampingan kepada anggota dalam melakukan kegiatan usahatani padi. Selain itu ketua kelompok memiliki karakter yang humanis dalam berinteraksi dengan anggota. Ketua kelompok tani memiliki kesadaran yang tinggi untuk memimpin rapat, memberikan informasi, dan melakukan pendampingan kepada anggota kelompok, hal tersebutlah yang menjadikan anggota merasa nyaman dengan kepemimpinan ketua kelompok tani dan ingin terus bergabung dalam kelompok tani.

Perilaku pemimpin

Menurut Kartono (2006), perilaku pemimpin yaitu usaha yang dilakukan pemimpin untuk selalu mempengaruhi aktivitas bawahanya dengan menciptakan komunikasi yang efektif agar terjalin hubungan kekeluargaan satu dengan yang lainya.
Berdasarkan hasil penelitian diketahui bahwa perilaku pemimpin sebagai panutan dalam melakukan aktivitas dan menjalin komunikasi dengan anggota berada pada klasifikasi cukup baik $(53,63 \%)$. Ketua kelompok tani memiliki karakter yang humanis artinya mampu menjalin komunikasi yang baik guna menimbulkan rasa percaya kepada anggota, sehingga anggota merasa ketua kelompok tani memiliki pengetahuan dan pengalaman yang lebih untuk dijadikan sebagai pedoman dalam berusahatani. Akan tetapi menurut anggota, terkadang ketua kelompok tani memiliki keterbatasan di dalam memberikan informasi atau ajakan dalam mengikuti setiap kegiatan kelompok, sehingga perlu adanya penyempurnaan fasilitas komunikasi di dalam kelompok seperti adanya poster dan mading agar ketua kelompok mampu memberikan informasi secara verbal maupun visual.

\section{Kekuasaan pemimpin}

Kekuasaan pemimpin adalah kemampuan pemimpin dalam mempengaruhi orang lain (Kartono 2006). Kekuasaan pemimpin diukur berdasarkan indikator kemampuan menumbuhkan ide untuk kelompok dan memberikan kebebasan anggotanya dalam berusahatani. Berdasarkan hasil penelitian diketahui bahwa kekuasaan pemimpin berada pada klasifikasi cukup baik $(50,73 \%)$. Ketua kelompok mampu memberikan ide atau gagasan di dalam merancang kegiatan kelompok tani. Selain itu menurut anggota, ketua kelompok memiliki inisiatif di dalam memutuskan mana yang terbaik dalam berbagai permasalahan yang ada di kelompok tani seperti perbedaan pendapat antar anggota kelompok.

Tabel 1. Rekapitulasi responden berdasarkan kepemimpinan ketua kelompok

\begin{tabular}{cccc}
\hline $\begin{array}{c}\text { Selang } \\
\text { (skor) }\end{array}$ & Klasifikasi & $\begin{array}{c}\text { Jumlah } \\
\text { ketua } \\
\text { (Orang) }\end{array}$ & $\begin{array}{c}\text { Persentase } \\
(\%)\end{array}$ \\
\hline$(40,53-47,15)$ & Kurang baik & 15 & 21,73 \\
$(47,16-53,78)$ & Cukup baik & 35 & 50,73 \\
$(53,79-60,41)$ & Baik & 19 & 27,54 \\
\hline Jumlah & & 69 & 100 \\
\hline Rata-rata : 50,66 & (Cukup baik) & \\
\hline
\end{tabular}


Tabel 2. Klasifikasi berdasarkan kepemimpinan ketua kelompok tani

\begin{tabular}{lcccc}
\hline Indikator & Skor & Klasifikasi & $\begin{array}{c}\text { Jumlah } \\
\text { Ketua } \\
(\text { Orang) }\end{array}$ & $\begin{array}{c}\text { Persentase } \\
(\%)\end{array}$ \\
\hline $\begin{array}{l}\text { - Sifat } \\
\text { - Pemimpin }\end{array}$ & 23,98 & Baik & 29 & 42,03 \\
- Perilaku & 16,96 & $\begin{array}{c}\text { Cukup } \\
\text { baik }\end{array}$ & 37 & 53,63 \\
- pemimpin & & 35 & 50,73 \\
- Kekuasaan & 10,73 & $\begin{array}{c}\text { Cukup } \\
\text { pemimpin }\end{array}$ & 35 & \\
\hline
\end{tabular}

Tabel 3. Rekapitulasi kelompok berdasarkan tingkat kedinamisan kelompok

\begin{tabular}{lccc}
\hline Selang (skor) & Klasifikasi & $\begin{array}{c}\text { Jumlah } \\
\text { kelompok }\end{array}$ & $\begin{array}{c}\text { Persentase } \\
(\%)\end{array}$ \\
\hline$(72,10-93,00)$ & Kurang dinamis & 14 & 20,29 \\
$(93,01-113,91)$ & Cukup dinamis & 39 & 56,52 \\
$(113,92-134,80$ & Dinamis & 16 & 23,19 \\
\hline Jumlah & 69 & 100 \\
\hline Rata-rata: 103,40 & (Cukup dinamis) & &
\end{tabular}

\section{Dinamika kelompok}

Dinamika kelompok adalah tingkah laku kelompok dalam melakukan gerakan secara bersama yang dilakukan oleh anggota kelompok tani secara serentak dan bersama-sama dalam melaksanakan seluruh kegiatan kelompok tani dalam mencapai tujuan (Suhardiyono 1992). Dinamika kelompok dalam penelitian ini mengacu pada teori dinamika kelompok Mardikanto (1993), meliputi tujuan kelompok, struktur kelompok, fungsi tugas, pembinaan dan pemeliharaan kelompok, kekompakan kelompok, suasana kelompok, tekanan kelompok, keefektifan kelompok dan agenda terselubung.

Tabel 3 menunjukkan rekapitulasi kelompok berdasarkan tingkat kedinamisan kelompok yang ada di Kecamatan Natar Kabupaten Lampung Selatan. Berdasarkan hasil penelitian diketahui bahwa anggota dan ketua kelompok tani mempunyai keterkaitan emosional di dalam kelompok tani, hal tersebut terlihat dari sikap kegotong royongan, kebersamaan dalam menjalankan kegiatan kelompok tani, seperti pembuatan Rencana Defenitif Kelompok (RDK) dan Rencana Defenitif Kegiatan Kelompok (RDKK), pelatihan yang diberikan oleh dinas pertanian dan penyaluran bantuan saprodi dalam usahatani. Sikap kegotong-royongan yang dimiliki oleh anggota kelompok tani yang ada di Kecamatan Natar Kabupaten Lampung Selatan ini menciptakan kekompakan antara anggota dengan ketua kelompok dalam menjalankan kegiatan kelompok. Anggota kelompok tani merasa termotivasi ketika melihat salah satu anggota sedang mengikuti kegiatan kelompok maka anggota yang lainya ikut serta dalam kegiatan kelompok. Adanya sikap kegotong royongan dan kebersamaan antara anggota dan ketua membuat kedinamisan kelompok tani yang ada di Kecamatan Natar Kabupaten Lampung Selatan berada pada klasifikasi cukup dinamis $(56,52 \%)$ atau sebanyak 39 kelompok tani dari 69 kelompok.

Tabel 4 menunjukkan klasifikasi kelompok tani berdasarkan masing-masing indikator dalam dinamika kelompok. Indikator tersebut mengacu kepada teori dinamika kelompok yang dikemukakan oleh Mardikanto tahun 1993. Berikut ini penjelasan dari setiap indikator dinamika kelompok di Kecamatan Natar Kabupaten Lampung Selatan.

Tujuan kelompok

Tujuan kelompok sebagai hasil akhir atau keadaan yang diinginkan oleh semua anggota kelompok (Mardikanto 1993). Tujuan kelompok diukur berdasarkan indikator tujuan kelompok yang dianalisis berdasarkan kejelasan dan kesesuaian tujuan kelompok dengan anggota dan proses pengambilan keputusan di dalam kelompok.

Tabel 4. Klasifikasi berdasarkan kelompok indikator dinamika kelompok

\begin{tabular}{lclcc}
\hline $\begin{array}{l}\text { Indikator } \\
\text { dinamika } \\
\text { kelompok }\end{array}$ & Skor & Klasifikasi & $\begin{array}{c}\text { Jumlah } \\
\text { kelompok }\end{array}$ & $(\%)$ \\
\hline $\begin{array}{l}\text { - Tujuan } \\
\text { kelompok }\end{array}$ & 9,55 & Cukup jelas & 44 & 63,77 \\
$-\begin{array}{l}\text { Struktur } \\
\text { kelompok }\end{array}$ & 13,60 & Kurang sesuai & 47 & 68,12 \\
- Tugas & 14,57 & Cukup sesuai & 31 & 44,93 \\
$\begin{array}{l}\text { kelompok } \\
\text { - Pembinaan }\end{array}$ & 14,68 & Cukup sesuai & 41 & 59,42 \\
$\begin{array}{l}\text { kelompok } \\
\text { Kekompakan }\end{array}$ & 14,22 & Cukup kompak & 44 & 63,78 \\
$\begin{array}{l}\text { kelompok } \\
\text { - Suasana } \\
\text { kelompok }\end{array}$ & 12,56 & Cukup nyaman & 34 & 49,27 \\
$-\begin{array}{l}\text { Tekanan } \\
\text { kelompok }\end{array}$ & 8,07 & Cukup sesuai & 31 & 44,93 \\
- Keefektifan & 8,49 & Cukup efektif & 30 & 43,47 \\
- kelompok & & & & \\
$-\begin{array}{l}\text { Agenda } \\
\text { terselubung }\end{array}$ & 7,67 & Cukup tercapai & 30 & 43,47 \\
\hline
\end{tabular}


Berdasarkan hasil penelitian menunjukkan bahwa kejelasan tujuan kelompok tani, kesesuaian tujuan kelompok dengan anggota dan proses pengambilan keputusan berada pada klasifikasi cukup jelas $(63,77 \%)$, artinya anggota dan ketua telah mengetahui tujuan kelompok tani. Anggota kelompok tani mengetahui dari keaktifan ketua kelompok tani dalam memberikan informasi yang terkait dengan tujuan didirikanya kelompok tani dan alasan untuk petani perlu bergabung dengan kelompok tani. Menurut anggota kelompok tani yang ada di Kecamatan Natar Kabupaten Lampung Selatan kesesuaian antara tujuan pribadi dengan tujuan kelompok memiliki kesamaan hal tersebut terjadi karena dalam proses penentuan tujuan suatu kegiatan ketua dan anggota selalu mengadakan rapat untuk menentukan secara bersama tujuan dari setiap kegiatan.

\section{Struktur kelompok}

Berdasarkan hasil penelitian menunjukkan bahwa struktur yang ada di kelompok tani Kecamatan Natar Kabupaten Lampung Selatan berada pada klasfikasi kurang sesuai $(68,12 \%)$, artinya keikutsertaan dalam pengambilan keputusan, adanya pembagian tugas, sistem komunikasi dan sarana interaksi yang tersedia tidak berjalan dengan maksimal. Hal tersebut terjadi karena pembentukan struktur kepengurusan kelompok dipilih atas dasar kedekatan emosional saja antara ketua dan anggota dan tidak berdasarkan kemampuan masing-masing anggota, sehingga mengakibatkan pelaksanaan kegiatan seperti pencatatan bantuan, hasil rapat dan kondisi keuangan, menjadi kendala tersendiri dalam kelompok tani.

\section{Fungsi tugas}

Fungsi tugas, yaitu kegiatan yang harus dilakukan kelompok dalam rangka mencapai tujuan. Fungsi tugas diukur berdasarkan indikator kepuasan anggota terhadap pembagian tugas, kejelasan informasi dan koordinasi antara anggota dengan ketua kelompok. Berdasarkan hasil penelitian menunjukkan bahwa fungsi tugas kelompok tani yang ada di Kecamatan Natar Kabupaten Lampung Selatan berada pada klasifikasi cukup sesuai (44,93\%). Merujuk pada indikator fungsi tugas, anggota dan ketua kelompok telah mengetahui fungsinya masing-masing didalam menjalankan kegiatan kelompok, namun menurut anggota ketua kelompok perlu meningkatkan koordinasi dengan semua anggota ketika ada kegiatan dalam kelompok tani, sehingga anggota merasa keberadaannya dalam kelompok tani dibutuhkan.

Pembinaan dan pemeliharaan kelompok

Pembinaan dan pemeliharaan kelompok (group building and maintenance), Pembinaan dan pemeliharaan kelompok diukur berdasarkan indikator kegiatan kelompok dan ketersediaan fasilitas yang mendukung dalam kegiatan kelompok. Berdasarkan hasil penelitian menujukkan bahwa kesesuaian dan ketersediaan fasilitas yang mendukung dalam kegiatan kelompok berada pada klasifikasi cukup sesuai $(59,42 \%)$. Sebagian kelompok tani telah menyediakan fasilitas anggota guna menunjang kegiatan kelompok seperti peningkatan kemampuan anggota dengan melalui kegiatan pelatihan-pelatihan, kunjungan ke demplot, sedangkan fasilitas yang terkait dengan sarana dan prasarana penunjang kegiatan usahatani padi di Kecamatan Natar Kabupaten belum tersedia.

\section{Kekompakan kelompok}

Kekompakan kelompok (group cohesiveness), yaitu rasa keterikatan anggota kelompok terhadap kelompoknya. Kekompakan kelompok di ukur berdasarkan indikator ketua kelompok dalam mengkoordinir anggota untuk mengikuti kegiatan kelompok dan tingkat kenyamanan anggota dalam kelompok. Berdasarkan penelitian menujukkan bahwa kekompakan yang terjadi antara anggota dan ketua kelompok yang ada di Kecamatan Natar Kabupaten Lampung Selatan berada pada klasifikasi cukup kompak (63,78\%), artinya ketua kelompok mampu mengkoordinir anggota dalam mengikuti kegitan kelompok tani. Menurut anggota kekompakan yang terjadi dalam kelompok terjadi karena sikap kegotong royongan yang dimiliki oleh anggota dan ketua kelompok dalam menjalankan kegiatan kelompok tani. sikap kegotong royongan tersebut terlihat ketika kelompok tani melakukan rapat, anggota bergantian memberikan sumbangan tenaga, pemikiran dan dana untuk menyelenggarakan kegiatan tersebut. Sikap kegotong royongan kelompok yang sudah baik tersebut dimaksimalkan oleh ketua kelompok dengan mengkoordinir anggota agar selalu menjaga kekompakan kelompok.

Suasana kelompok

Berdasarkan hasil penelitian diketahui bahwa suasana kekeluargaan yang diwujudkan dalam setiap kegiatan kelompok dan kesempatan 
berpartisipasi dalam mengeluarkan pendapat berada pada klasifikasi cukup nyaman $(49,27 \%)$. Menurut Mardikanto (1993) suasana kelompok (group atmosphere), yaitu lingkungan fisik dan nonfisik yang akan mempengaruhi perasaan setiap anggota kelompok terhadap kelompoknya. Suasana kelompok yang ada di kelompok tani Kecamatan Natar diklasifikasikan kedalam kategori cukup dinamis, hal tersebut terjadi karena proses komunikasi dan interaksi antara anggota dan ketua kelompok yang baik dalam menjalankan kegiatan kelompok. Kegiatan kelompok tani berjalan dengan baik tidak terlepas dari upaya untuk saling menghargai dan percaya satu dengan lainya, sehingga menimbulkan kenyamanan bagi anggota untuk terus menjalankan kegiatan usahatani.

Tekanan kelompok

Tekanan kelompok (group pressure), yaitu tekanan atau ketegangan dalam kelompok yang menyebabkan kelompok tersebut berusaha keras mencapai tujuan kelompok. Tekanan kelompok diukur berdasarkan indikator adanya peraturan dan sanksi dalam kelompok. Merujuk pada indikator tekanan kelompok, tekanan yang terjadi pada kelompok tani di Kecamatan Natar Kabupaten Lampung Selatan berada pada klasifikasi cukup sesuai $(44,93 \%)$, artinya sebagian besar kelompok memiliki aturan yang harus di tepati oleh anggota maupun ketua kelompok. Aturan tersebut digunakan oleh kelompok untuk mengontrol perilaku anggota dan ketua dalam kelompok. Menurut ketua kelompok aturan tersebut berupa sanksi bagi anggota yang melanggar peraturan dan penghargaan bagi anggota yang telah melaksanakan kegiatan usaha tani sesuai dengan Rancangan Defenitif Kegiatan Kelompok (RDKK).

\section{Keefektifan kelompok}

Keefektifan kelompok (group effectiveness), yaitu keberhasilan kelompok untuk mencapai tujuannya, yang dapat dilihat pada tercapainya keadaan atau perubahan (fisik dan nonfisik) yang memuaskan anggotanya. Keefektifan kelompok diukur berdasarkan indikator keberhasilan dalam mencapai tujuan kelompok. Berdasarkan penelitian menunjukkan bahwa kelompok tani yang ada di Kecamatan Natar Kabupaten Lampung Selatan cukup efektif dalam menjalankan fungsinya sebagai tempat belajar, wahana kerjasama dan unit produksi petani sudah dijalankan oleh kelompok.

Sebanyak 30 atau 43,47 persen kelompok tani berada pada klasifikasi cukup efektif dalam mencapai tujuan kelompok. Keberhasilan kelompok tani yang ada di Kecamatan Natar Kabupaten Lampung Selatan dalam menjalankan fungsi tugasnya sebagai kelompok terlihat dari meningkatkan perolehan produktivitas padi dalam satu musim tanam yang dialami oleh anggota. Peningkatan produktivitas padi tersebut menurut anggota kelompok, mereka merasa senang dan nyaman dengan bergabung dalam kelompok tani karena dengan bergabung dengan kelompok tani mereka bisa merasakan program dari pemerintah, mudah memecahkan masalah, saling berinteraksi untuk belajar dan mengembangkan kemampuan dalam berusahatani untuk meningkatkan produktivitas padi.

Agenda terselubung

Agenda terselubung (hidden agenda), yaitu tujuan pribadi anggota yang sengaja tidak diberitahukan kepada anggota lainya yang ingin dicapai ketika bergabung dengan kelompok dalam melakukan aktifitas kelompok. Berdasarkan penelitian menunjukkan bahwa agenda terselubung yang ada pada kelompok tani di Kecamatan Natar Kabupaten Lampung Selatan berada pada klasifikasi cukup tercapai $(43,47 \%)$. Kondisi tersebut terjadi karena tujuan tersembunyi yang dimiliki oleh anggota ketika bergabung dalam kelompok tani telah tercapai. Tujuan tersebut seperti anggota kelompok lebih mudah dalam mengembangkan kemampuan usahatani, merasakan program yang diberikan oleh pemerintah setempat, kemudahan dalam memperoleh pupuk, benih dan bantuan modal.

\section{Produktivitas padi}

Menurut Kartasapoetra (1988) produktivitas adalah hasil kegiatan usahatani yang diperoleh dari lahan garapan petani selama satu musim yang diukur dalam ton/ha. Tabel 5 menunjukkan bahwa produktivitas padi kelompok tani yang ada di Kecamatan Natar Kabupaten Lampung Selatan berada pada $(6,96-8,30)$ ton/ha, yakni 34 kelompok tani $(49,28 \%)$. Kondisi tersebut menunjukkan bahwa produktivitas padi yang ada di kelompok tani Kecamatan Natar berada dalam klasifikasi sedang.

mencerminkan bahwa adanya upaya dari anggota kelompok tani untuk bekerja dengan baik sehingga dapat melakukan usahatani mulai dari penyiapan lahan, penyiapan benih, pemupukan dan perawatan 
Tabel 5. Klasifikasi kelompok berdasarkan produktivitas padi

\begin{tabular}{cccc}
\hline $\begin{array}{c}\text { Selang } \\
\text { (ton/ha) }\end{array}$ & Klasifikasi & $\begin{array}{c}\text { Jumlah } \\
\text { kelompok }\end{array}$ & $\begin{array}{c}\text { Persentase } \\
(\%)\end{array}$ \\
\hline$(5,61-6,95)$ & Rendah & 25 & 36,23 \\
$(6,96-8,30)$ & Sedang & 34 & 49,28 \\
$(8,31-9,65)$ & Tinggi & 10 & 14,49 \\
\hline Jumlah & & 69 & 100 \\
\hline Rata-rata : 6,70 & (Sedang) & & \\
\hline
\end{tabular}

Tabel 6. Hasil analisis kepemimpinan dengan dinamika kelompok

\begin{tabular}{|c|c|c|c|c|}
\hline Variabel (X) & $\begin{array}{l}\text { Variabel } \\
\text { (Y) }\end{array}$ & $\begin{array}{c}\text { Koefisien } \\
\text { korelasi }\left(r_{s} \text {. }\right.\end{array}$ & $\begin{array}{l}\text { Signifikan } \\
\text { (2-tailed) }\end{array}$ & $\begin{array}{c}\mathrm{T}- \\
\text { hitung }\end{array}$ \\
\hline Kepemimpinan & $\begin{array}{l}\text { Dinamika } \\
\text { kelompok }\end{array}$ & $0.321 *$ & 0,007 & 2,774 \\
\hline $\begin{array}{l}\text { Keterangan: } \\
\mathrm{r}_{\mathrm{s}} \text { : Korelasi Rank } \\
* \text { : Nyata pada tar }\end{array}$ & $\begin{array}{l}\text { Spearman } \\
\text { f kepercayaan }\end{array}$ & $95 \%(\alpha=0,05)$ & & \\
\hline
\end{tabular}

Tabel 7. Hasil analisis dinamika kelompok tani dengan produktivitas

\begin{tabular}{|c|c|c|c|c|}
\hline Variabel (X) & $\begin{array}{c}\text { Variabel } \\
\text { (Y) }\end{array}$ & $\begin{array}{c}\text { Koefisien } \\
\text { korelasi }\left(r_{s} \text {, }\right.\end{array}$ & $\begin{array}{c}\text { Signifikan } \\
\text { (2-tailed) }\end{array}$ & $\begin{array}{c}\text { T- } \\
\text { hitung }\end{array}$ \\
\hline $\begin{array}{l}\text { Dinamika } \\
\text { kelompok }\end{array}$ & Produktivitas & -0.203 & 0.094 & 1,696 \\
\hline $\begin{array}{l}\text { Keterangan: } \\
\mathrm{r}_{\mathrm{s}} \text { : Korelasi Rank } \\
* \text { : Nyata pada ta } \\
\text { tn : tidak nyata. }\end{array}$ & $\begin{array}{l}\text { k Spearman } \\
\text { araf kepercayaan }\end{array}$ & $95 \%(\alpha=0,05)$ & & \\
\hline
\end{tabular}

Berdasarkan kondisi di lapangan rata-rata produktivitas padi kelompok tani yakni 6,70 ton/ha lebih tinggi dari pada produktivitas padi di Kabupaten Lampung Selatan yaitu 5,69 ton/ha, artinya terjadi selisih sebesar sebesar 1,01 ton/ha. Selisih produktivitas padi yang terjadi tersebut

\section{Hubungan antara kepemimpinan ketua kelompok dengan dinamika kelompok di Kecamatan Natar}

Hasil analisis hubungan antara variabel kepemimpinan dengan dinamika kelompok, dianalisis dengan statistika non parametrik uji korelasi Rank Spearman dapat dilihat pada Tabel 6. Tabel 6 menunjukkan hasil analisis hubungan antara kepemimpinan ketua kelompok tani dengan dinamika kelompok diperoleh hasil $\mathrm{t}$ hitung sebesar 2,774 lebih besar dari pada t tabel yaitu 1,994. Hal tersebut menunjukkan bahwa kepemimpinan ketua kelompok tani berhubungan nyata dengan dinamika kelompok. Kondisi tersebut berarti bahwa ketua kelompok tani menentukan kedinamisan kelompok tani. Ketua kelompok mempunyai sifat yang humanis dalam memimpin rapat dan menujukan perilaku yang megayomi anggota dengan memberikan informasiinformasi usahatani, selain itu ketua kelompok tani juga memberikan kebebasan sepenuhnya kepada anggota dalam berusahatani padi.

Kemampuan ketua kelompok tani dalam mengkoordinir anggota kelompok tani juga di imbangi dengan kemampuan interaksi yang cukup baik yang dilakukan oleh ketua kelompok dan Petugas Penyuluh Lapang (PPL) sehingga terjalin komunikasi yang baik antara ketua dan PPL dalam berkoordinasi dengan anggota dalam kegiatan usahatani. Koordinasi yang baik antara PPL dan Ketua kelompok ditunjukkan dengan adanya rapat yang dilakukan secara bersama. Menurut BP3K Natar (2015), pertemuan antara kelompok dan PPL bertujuan untuk mencari masalah yang ada dilapangan dan untuk mencari teknologi yang tepat dalam mengatasi permasalahan tersebut, selain itu pertemuan kelompok juga berfungsi sebagai wadah untuk masuknya suatu program atau bantuan dari pemerintah sehingga kelompok dapat menyampaikan lebih dekat dengan anggota. Oleh karena itu ketua kelompok tani selalu menekankan kepada anggota kelompok tani untuk melakukan rapat kelompok. Upaya yang dilakukan oleh ketua kelompok dalam mengajak anggota yaitu secara persuasif dan menunjukan sifat kepemimpinan yang humanis.

Kepemimpinan yang humanis merupakan salah satu ciri bahwa kepemimpinan ketua kelompok efektif Mutmaimanah (2014). Hasil penelitian ini sejalan dengan penelitian Yunasaf (2004) dan Hastuti et al. (2010) yang menyebutkan bahwa kepemimpinan ketua kelompok tani berhubungan dalam mendinamiskan kelompok.

\section{Hubungan antara dinamika kelompok dengan Produktivitas padi di Kecamatan Natar Kabupaten Lampung Selatan}

Hasil analisis korelasi Rank Spearman antara dinamika kelompok dengan produktivitas dianalisis dengan menggunakan statistika non parametrik uji korelasi Rank Spearman dapat dilihat pada Tabel 7. Tabel 7 menunjukkan hasil analisis hubungan antara variabel dinamika kelompok dengan produktivitas. Berdasarkan hasil pengujian hipotesis menggunakan uji korelasi Rank Sperman antara dinamika kelompok dengan produktivitas padi diperoleh hasil t hitung sebesar 
1,696 lebih kecil dari pada t tabel yaitu 1,994. Hal ini menunjukkan bahwa dinamika kelompok tidak berhubungan dengan produktivitas padi di Kecamatan Natar Kabupaten Lampung Selatan. Berdasarkan kondisi di lapangan tingkat kedinamisan kelompok tani sudah cukup baik dan produktivitas padi cukup tinggi, akan tetapi kedua variabel tersebut tidak berhubungan satu sama lain. Kondisi tersebut terjadi karena rendahnya keatifnya anggota dalam mengikuti rapat kelompok dan ketidakkonsistennya pemberian sanksi yang diberikan oleh kelompok tani menjadi penyebab dinimika kelompok tidak berhubungan dengan produktivitas. Hasil penelitian ini tidak sejalan dengan penelitian Jamaluddin dan Herdiansyah (2017) dan Sari et al. (2014) yang menyebutkan bahwa semakin dinamis kelompok maka semakin tinggi tingkat produktivitas.

\section{KESIMPULAN}

Berdasarkan hasil penelitian disimpulkan bahwa : Kepemimpinan ketua kelompok tani di Kecamatan Natar Kabupaten Lampung Selatan berada pada klasifikasi cukup baik, tingkat kedinamisan kelompok yang ada di kelompok tani di Kecamatan Natar Kabupaten Lampung Selatan tergolong dalam klasifikasi cukup baik, artinya kelompok tani sudah cukup berhasil dalam menjalankan fungsinya sebagai wadah, tempat belajar untuk meningkatkan kemampuan anggota kelompok tani dalam berusahatani, kepemimpinan ketua kelompok tani di Kecamatan Natar Kabupaten Lampung Selatan berhubungan nyata terhadap dinamika kelompok dan dinamika kelompok tidak berhubungan nyata dengan produktivitas.

\section{DAFTAR PUSTAKA}

Arifin B. 2013. Ekonomi Pembangunan Pertanian. IPB Press. Bogor

BP3K Natar. 2015. Jumlah Kelompok Tani di Kecamatan Natar. BP3K Natar. Lampung Selatan.

Hastuti Y, Hasanudin T dan Sadar S. 2010. Hubungan karakteristik dan perilaku pemimpin dengan dinamika kelompok usaha dalam meningkatkan pendapatan rumah tangga di Desa Margasari Kecamatan Labuhan Maringgai Kabupaten Lampng Timur. Skripsi. http://digilib.unila.ac.id/ 20331/1/YEVI\%20HASTUTI.pdf. [21 Juli 2017].

Jamaluddin HR. 2017. Kajian hubungan dinamika kelompok tani dengan kemampuan kelompok tani di Kecamatan Batang Asam Kabupaten Tanjung Jabung Barat. Jurnal Ilmiah Ilmu Terapan Universitas Jambi, 1 (1) : 64-74. https://online-journal.unja.ac.id/index.php/J ITPM/article/view/3751. Universitas Jambi. [21 Juli 2017].

Kartono K. 2006. Pemimpin dan Kepemimpinan. Jakarta : Raja Grafindo Persada.

Kartasapoetra. 1988. Kerusakan Tanah Pertanian

dan Usaha Untuk Merehabilitasinya. Swadaya. Jakarta.

Mardikanto T. 1993. Penyuluhan Pembangunan Pertanian. Surakarta: Sebelas Maret University Press.

Mutmainah R. 2014. Peran kepemimpinan kelompok tani dan efektivitas pemberdayaan petani. Jurnal Sosiologi Pedesaan, 2 (3) : 182-199. http://journal.ipb.ac.id/index.php/ sodality/article/viewFile/9425/7388. Institut Pertanian Bogor. [10 Mei 2017].

Sari U, Viantimala B, dan Nurmayasari I. 2014. Analisis hubungan dinamika kelompok dengan tingkat penerapan pengelolaan tanaman terpadu (PTT) dan produktivitas usahatani padi sawah di Desa Palas Aji Kecamatan Palas Kabupaten Lampung Selatan. JIIA, 2 (1) : 86-94. http://jurnal. fp.unila.ac.id/index.php/JIA/article/view/565. Universitas Lampung. [10 Mei 2017].

Siegel S. 1986. Statistik Non-Parametrik Ilmuilmu Sosial. PT Gramedia Pustaka Utama. Jakarta.

Suhardiyono I. 1992. Penyuluhan Petunjuk bagi Penyuluh Pertanian. Erlangga. Jakarta.

Yunasaf U. 2004. Kepemimpinan pengurus dalam mendinamiskan organisasi koperasi (kasus pada koperasi serba usaha) Tandangsari Sumedang. Jurnal Sosiohumaniora, 6 (3) : 232-244. http://jurnal.unpad.ac.id/sosiohumaniora/article/view/5531/2893. Universitas Padjajaran. [10 Mei 2017]. 